\title{
A POTENCIÁLMODELL ERÉNYEI ÉS KORLÁTAI A TÁRSADALOMKUTATÁSBAN ${ }^{1}$
}

\author{
(Virtues and Limits of Potential Model)
}

\section{TAGAI GERGELY}

Kulcsszavak:

potenciálmodell térkapcsolatok terïleti elemzés

A tanulmány a potenciálmodell alkalmazásának alapkérdéseit vizsgálja. Ennek keretében a szerző áttekinti a modell müködési mechanizmusának, elméleti igazolásának néhány alapvetö problémáját, felépitésének és speciális változatainak sajátosságait. A modell erényei és korlátai nem direkt szembeállitás során kerülnek számbavételre, hanem a jellegzetes használati kérdések feltárásával és értékelésével. Az alkalmazások összetett rendszere nemcsak a modell, illetve a potenciál-fogalom sokszinüségére utal, hanem rávilagit a helyére a területi elemzésekben, különösen a térkapcsolatok vizsgálatában.

\section{Bevezetés}

A társadalom térbeli jelenségeinek, folyamatainak megismeréséhez különleges szemléletet nyújtanak a fizikai analógián alapuló, vagy térbeli egymásrahatási modellek. Általuk a társadalmi tér jellemzőit nem elsősorban az egyéni sajátosságokon keresztül vizsgálhatjuk, hanem a térbeli egységek közötti kapcsolatrendszerek feltárásával. Ezek megismerésére és magyarázatára született meg a potenciálmodell, amely már évtizedek óta elöszeretettel alkalmazott módszere a kvantitatív terủleti kutatásoknak.

A tanulmány abból a módszertani érdeklödésből fakadóan született, ami elsösorban a modellépítés alapvető kérdéseivel kapcsolatos. Hova vezethető vissza a potenciál-koncepció társadalomtudományi alkalmazása? Milyen problémák, kérdések vetỏdhetnek fel a modellezési eljárás során, és hogyan oldhatók ezek meg? Hogyan lehet interpretálni a különbözỏ modellek eredményeit? Ezeknek a kérdéseknek a feltárása a modell mechanizmusának értelmezésén túl a potenciálmodell erényeire és korlátaira is rávilágít.

\section{A potenciál-koncepció alapjai}

A természettudományok fejlődésével együtt bontakozott ki az elmúlt évszázadok során az a gondolat, hogy a társadalom jelenségei is igaznak bizonyulhatnak az általános érvényủ természeti törvények. Ennek nyomán jelent meg a szociálfizikai elképzelés, amely a társadalom elemeit (egyedeket, csoportokat) tömegszerü testekként kezelve kívánta leírni, alkalmazva rájuk a fizikában ismert összefüggéseket. Ennek jellemzó példája lehet a gravitációs modell, amely a Newton által leírt 
Tagai Gergely : A potenciálmodell erényei és korlátai a társadalomkutatásban.

Tér és Társadalom 21. évf. 2007/1. 145-158. p.

146 Tagai Gergely

TÉT XXI. évf. 2007

tömegvonzási törvény formulájához $\left(F=f \frac{m_{a} m_{b}}{r^{2}}\right)$ hasonlóan, a testek között fennálló vonzóerőt a testek tömege és egymástól való távolságuk függvényében kívánja megadni. Ezt az összefüggést elöször Henry Charles Carey írta le, aki úgy gondolta, hogy a nagyobb társadalmi tömegek nagyobb eröt képesek kifejteni, illetve a gravitáció éppen úgy vonatkozik a társadalomra, mint ahogy a fogalom eredeti értelmében használatos (Carey 1859). Az elmúlt százötven év alatt a gravitációs modell, alapelemeit megtartva, lassan átalakult (számos kutató ötletességének köszönhetően, lásd pl. Schäffle 1878; Ravenstein 1889; Young 1924), és egyre általánosabb formát öltött.

A potenciálmodell életre hívása elsősorban John Quincy Stewart, amerikai asztrofizikus nevéhez fủződik, aki a múlt század harmincas évei végén, negyvenes évei elején megkísérelte igazolni a gravitációs törvény társadalomtudományi alkalmazását, és általánosítani azt. Ennek során egy lépcsózetes egyszerüsítési folyamat eredményeképpen határozta meg a következő fogalmakat:

$$
F=\frac{G M m}{d^{2}},
$$

ahol $F$ a hatóerő nagysága $M$ és $m$ testek között $d$ távolság függvényében, $G$ gravitációs konstanssal kiegészítve;

$$
E=\frac{G M m}{d},
$$

amelyben a két tömeg kölcsönhatásának energiája $E$, valamint

$$
V_{A}=\frac{G m}{d} \text {, }
$$

ami a $V_{A}$ gravitációs potenciált jelöli, amely $m$ tömeg $A$ ponton végzett 'munkájával' rokonítható (Stewart 1948).

Ezzel az összefüggéssel Stewart eljutott a társadalmi tömegként értelmezhető jelenségek, valamint a távolság, az egymáshoz viszonyított helyzet kapcsolatát legegyszerübben szemléltető formulához (továbbiakban $m / d$ ). Az $m / d$ összefüggés általánosítása a fizikus Lagrange nevéhez füzödik, aki a bolygómozgásokkal kapcsolatos számítások lényegét kívánta szemléltetni ezen a módon (Stewart 1947). Lagrange megfigyelése a későbbiek során átértelmezve vált alapjává az elektrosztatikus és a mágneses potenciál koncepciójának. De mint láthatjuk, beépülve a társadalom térbeli viszonyairól alkotott elképzelésekbe, ez az alapja a gravitációs modellnek és a potenciálmodellnek is. Anélkül, hogy a fizikai megfigyelés eredményeit ültetnénk át érvényes törvényként a társadalom mủködésére, az $\mathrm{m} / \mathrm{d}$ összefüggés kellóképpen alátámaszthatja az úgynevezett térbeli kölcsönhatási modellek használhatóságát és érvényességét, mert az $\mathrm{m} / \mathrm{d}$ formula elve nagymértékben egybevág azzal a statisztikai jellegủ tapasztalattal, ,miszerint a térbeli jelenségek kölcsönösen hatással vannak egymásra, az egymáshoz közelebbi jelenségek nagyobb, a távolabbi jelenségek kisebb hatással" (Dusek 2003, 45). Ez az elv tulajdonképpen megegyezik a Tobler Első Törvényeként elterjedt tétellel (Tobler 1970), azzal a 
kiegészítéssel élve, hogy a nagyobb súlyú jelenségek (tömegek) nagyobb hatást fejtenek ki, mint a kisebb súlyúak.

Visszatérve a Stewart által megfogalmazott potenciál értelmezéséhez, érdemes a további összefüggések ismertetéséhez általánosítani az általa jegyzett formulát:

$$
v_{i j}=\frac{m_{i}}{d_{i j}}
$$

ahol $v_{i j} i$ tömeg $j$ pontra kifejtett hatását jelöli, $d_{i j}$ pedig az $i$ tömeg és $j$ pont közötti távolságot adja meg. Ezzel leírható az adott tér két eleme közötti kapcsolat erőssége. Ez azután kiterjeszthető olyan módon, hogy az összefüggés ne csak két tömeg vagy pont közötti hatásokat jellemezze, hanem a tér minden egységének összesített potenciálja leírható legyen. Ehhez az egyes potenciálértékeket egyszerüen összegezni kell:

$$
V_{j}=\sum_{i} \frac{m_{i}}{d_{i j}}
$$

ahol $V_{j} \quad j$ összesített potenciálértékét jelzi. A potenciálmodell közvetlenül is levezethetö a gravitációs törvény formulájából, ha élünk bizonyos egyszerüsítő feltevésekkel, ahogyan ezt Pooler tette a potenciálmodellröl írt áttekintésében (Pooler 1987). Két tömeg ( $i$ és $j$ ) között fennálló kölcsönhatás erössége $\left(F_{i j}\right)$ a következő, a gravitációs modellből már ismert módon ragadható meg:

$$
F_{i j}=k \frac{m_{i} m_{j}}{d^{2}} .
$$

Ezt érdemes átalakítani úgy, hogy $k$ arányossági tényezöt eltávolítjuk, illetve a távolság négyzetes hatványkitevőjét általánosítjuk az egyszerüsítés érdekében:

$$
F_{i j}=\frac{m_{i} m_{j}}{d_{i j}^{b}} .
$$

A továbbiakban felírható az az eset, amikor az összes $i j$-re gyakorolt kölcsönhatásának erejét $\left(F_{j}\right)$ kívánjuk kimutatni. Ekkor

$$
F_{j}=\frac{m_{1} m_{j}}{d_{1 j}^{b}}+\frac{m_{2} m_{j}}{d_{2 j}^{b}}+\ldots+\frac{m_{n} m_{j}}{d_{n j}^{b}}=\sum_{i} \frac{m_{i} m_{j}}{d_{i j}^{b}} .
$$

Mivel $m_{j}$ minden egyes esetben azonos tömeget képvisel, tekinthetjük egységnyi értékủnek ( $m_{j}=1$ ), és ezáltal lehetőség nyîlik a következỏ egyszerüsítésre:

$$
\frac{m_{1}}{d_{1 j}^{b}}+\frac{m_{2}}{d_{2 j}^{b}}+\ldots+\frac{m_{u}}{d_{u j}^{b}}=\sum_{i} \frac{m_{i}}{d_{i j}^{b}}
$$

Ez a levezetés a Newton-i gravitációs összefüggés társadalmi térre vonatkoztatott elfogadására épüil. Ahogyan az már említésre kerültt, ez alapvetően hibás feltételezés volna, mégis a potenciálmodellt ebben a változatlan formulájában alkalmazzák 
Tagai Gergely : A potenciálmodell erényei és korlátai a társadalomkutatásban.

Tér és Társadalom 21. évf. 2007/1. 145-158. p.

leginkább, habár az elmúlt évtizedekben a tömeg és távolságértelmezések sokat fejlödtek (Sheppard 1979).

Az eddigiek alapján úgy tünik, a potenciálmodellben keveredik a fizikában használatos térerösség és potenciál fogalom (mármint, ha ragaszkodunk a fizikai analógiához). A potenciálszámítás menete a térerősség elvével mutat formai hasonlóságot, ebben az értelemben nem nevezhetjük a kiszámolt értékeket potenciálnak, mivel eredetileg mást jelöl ez a fogalom. A térerősség vizsgálatakor kifejezetten hangsúlyos tényező az irányultság kérdése: mint különböző erök összegzésével felépített mennyiség, a térerősség vektormennyiségként kezelendő. A potenciálmodell ezzel szemben közvetlenül nem veszi figyelembe az erőhatásokkal elvileg szintén együtt értelmezendő irányvektorokat, s ebben inkább a fizikai potenciálfogalomhoz hasonlít, amely szintén skalármennyiség. A potenciálszámítás eredményeiből felrajzolható 'erőtérben' közvetett módon következtethetünk bizonyos iránytényezőkre: az ekvipotenciális felületeket jelző görbékre merőlegest állítva kapjuk meg a potenciáltérben történő mozgás jellegzetes irányait. Talán az így felrajzolt eróvonalak rendszere feleltethető meg leginkább a térerősség fogalmának.

A potenciáltér felületjellege is ellentmond a térerősséggel való összekapcsolásának. Az azonos potenciálértékủ pontokat összekötő (izo)vonalak inkább rokoníthatók a fizikai térben az erővonalakra merölegesen elhelyezkedő potenciálfelületekkel, míg a térerősség jellemzöje, hogy az általa indukált erővonalak nem térhetnek vissza önmagukba, és ebböl kifolyólag nem képesek zárt felületet létrehozni. Az említett ellentmondások, amelyek a potenciálmodell és a hozzá köthetó rokon fizikai fogalmak között megfigyelhetők, ugyan nem kérdőjelezik meg a modell használhatóságát és múködési elvét, viszont utalnak arra, hogy a formai-logikai hasonlóság nem teremt tényleges analógiát.

\section{Potenciálváltozatok}

A potenciál számításának ismertetett módja az említett általánosítások és egyszerüsítések ellenére még mindig elég specifikus ahhoz, hogy a gyakorlatba átültetve néhány további nehézséggel szembesítse a modell alkalmazóját. Ezek főként a társadalmi és a fizikai tér eltérö jellegéböl adódnak. A potenciálmodell alkalmazásának szempontjából itt a fö különbség talán az lehet, hogy a fizikaival ellentétben a társadalmi tér jellemzően nem folytonos, hanem diszkrét. A társadalmi-gazdasági alakzatok (például a városok) rendszerint a tér egy-egy kitüntetett pontjában koncentrálódnak, 'tömegük' ehhez a ponthoz köthetö. Mivel az ilyen tömegpontok nem töltik ki a teret, csak nehezen lehetne egy lehatárolt térrész (például egy ország) bármely pontjának potenciálértékét megadni (ami természetesen függ az összes többi pont hatásától).

Hogy mégis hozzá lehessen jutni egy közelítő értékhez, azzal az absztrakcióval kell élni, hogy a lehatárolt térrészt azt teljesen kitöltő kisebb egységekre lehet bontani, így az egyes egységekhez (például régiók, megyék, települések stb.) hozzá lehet rendelni a bennük elhelyezkedő, kitüntetett pontok tömegét. Ezeket a területegységeket ezek után kiterjedt tömegpontként (kontrollpontok) kezelhetjük, úgy 
tekintve öket, mintha egy-egy reprezentatív pontjukba lenne koncentrálva minden érintett pont tömege (Bene-Tekse 1966). A reprezentatív pont megválasztása fontos lehet, bár a potenciáltér általános képének formálásában csak alárendelt szerepe van. A területegységek létéböl fakadóan (általában társadalmi akaratnak, irányítási szükségletnek köszönhetik létrejöttüket, formájukat) reprezentatív pontként nyilvánvaló választásnak tünhet közigazgatási központjuk (ha van ilyen). Ez, bár valóban az egyik legegyszerübb megoldás, bizonyos esetekben alkalmatlannak bizonyulhat: például ha a közigazgatási központok túlságosan közel esnek egymáshoz, viszont a területegységek egyéb (tömegükben esetleg mértékadó) pontjai között jelentös távolság is van. Ennél tehát célszerübb az adott területegységet társadalmigazdasági rendszerként értelmezve, annak valamely súlypontját tekinteni reprezentatív pontnak, vagy geometriai alakzatként, poligonként leírva a téregységet, centroidját választani (Warntz 1964).

A felvázolt, diszkrét térben érvényes potenciálmodell-alkalmazáson kívül számos ismert, de kevésbé elterjedt modellváltozat is létezik. Ezek valamilyen speciális tényező bevonásával egészítik ki az alapvetö összefüggést, és több esetben közvetlenül ki sem számolhatók, hanem (például integrálszámítással) csak egy közelítő értéket adnak a potenciálértékről. Az iránytényező bevonásának lehetőségét vizsgálta meg Sheppard, megkísérelve az egész potenciálkoncepció újragondolását (Sheppard 1979). Ennek során, munkájában a következő formulából indult ki:

$$
I_{i j}=k m_{i} a_{j} d_{i j}^{-n} \text {. }
$$

Anélkül, hogy részleteznénk a képlet összetevőinek jelentését, látható, hogy ez az összefüggés lényegét tekintve megegyezik a gravitációs modell általános formájával:

$$
F_{i j}=\frac{m_{i} m_{j}}{d_{i j}^{b}} \sim I_{i j}=k m_{i} a_{j} d_{i j}^{-n} .
$$

Annyi kiegészítést talán mégis érdemes tenni, hogy Sheppard formulájában a modell eredeti alakjában tömegként értelmezett $m_{i}$ és $a_{j}\left(m_{j}\right)$ értékek sajátos jelentést kapnak: $m_{i}$ vonzási hajlandóság, tehát annak a 'hajlamnak' a kifejeződése, hogy $m_{i}$ kölcsönhatásba lépjen, $a_{j}$ pedig a vonzerő mértéke. Ezek alapján a potenciál a következőképpen alakul:

$$
v_{i j}=\frac{k}{n-1} m_{i} a_{j} d_{i j}^{-n+1} \text {. }
$$

Ez az értelmezés arra helyezi a hangsúlyt, hogy mivel $I_{i j}$ nem egyenlő $I_{j i}$-vel, és ugyanígy ez az összefüggés $v_{i j}$ és $v_{j i}$ között is igaznak bizonyul, az interakció iránya megállapítható.

A folytonos térben a potenciálmodell Stewart által létrehozott formuláját alkalmazni nem lehet. Utóbbi esetben azzal a feltételezéssel élve, hogy a tömeg eloszlása 
Tagai Gergely : A potenciálmodell erényei és korlátai a társadalomkutatásban.

Tér és Társadalom 21. évf. 2007/1. 145-158. p.

egy egyenletes felszínre $(\theta)$ korlátozódik, azaz maga is folytonos, a potenciál értéke bármely $j$ pontban kifejezhető a következő határozott integrállal:

$$
V_{j}=\int_{(\theta)}^{1} \frac{1}{d} D d S,
$$

ahol $D d S$ terület bármely végtelenül kicsi (elemi) egységének tömegeloszlása (például népesség), $d$ pedig $j$ pont és $d S$ területegység közötti távolságot jelöli. Az integrálás kiterjeszthető a felszín mindazon elemeire, ahol az érték nem nulla. Az összefüggésböl adódik, hogy ezekkel a feltételezésekkel élve $d S$ terület minden egyes részének, amely $d$ távolságra van adott ponttól, $\frac{D d S}{d}$ potenciálérték felel meg (Bene-Tekse 1966). A hasonlóság az integrál-formula és a gravitációs modellböl származtatható alapmodell között azonnal szembetünik. Nem véletlenül, hiszen az integrálszámítás ugyanúgy összeadáson alapszik (Kulcsár 1998). Az egyes potenciálok összege ebben az esetben viszont csak közelító eredménnyel adható meg. A folytonos térben, integrálással kiszámolt potenciálmodell-variáció már a korai, a témához kötödö munkákban is említésre került példaként (Stewart 1948; Warntz 1955), a fenti nehézségek miatt azonban, a gyakorlatban nem nagyon alkalmazzák. Az összefüggés matematikai értelmezése és levezetése olvasható Sheppard már említett munkájában (Sheppard 1979).

Sheppard arról is beszámol, hogy az integrál-formula bevezetése mellett, a Stouffer által kifejlesztett közbeesö lehetőség modelljének (Stouffer 1940) tömeg alapú kölcsönhatásokra való alkalmazása is egy lehetséges módja a potenciálmodell folytonos térben történỏ 'mủködtetésére'. Ebben az esetben nem határozható meg egy általános képlet a potenciálértékekre, mivel minden eset, minden példa egyedi, és az éppen aktuális lehetöségek eloszlásától függ.

\section{A potenciálmodell részei és ezek összekapcsolása}

A potenciálszámítás elterjedt formulája alapján nem határozható meg adott tömeg önmagára gyakorolt hatása. Mivel a tömegek önmaguktól való távolsága első megközelítésben nulla, a sajátpotenciál direkt módon nem számolható ki, elkerülendö a nullával való osztást. Ennek feloldása érdekében többféle megoldással is élhetünk. Lehetséges például az, hogy az érintett tömeget (területet), kisebb részekre osztjuk, dezaggregáljuk. Végtelen számú egységre osztva a tömeget, az integrál-formula alapján elvégzett számítás megfelelő közelítést nyújt a sajátpotenciál értékéről (Pooler 1987). De nem kell végtelen számú egységet létrehoznunk ahhoz, hogy megértsük, hogy a dezaggregálás hogyan hat egy tömeg saját erejére. Belátható, hogy ha a testek között valamiféle hatóerőket tételezünk fel, akkor a hatóerỏk összessége több, mint ha csak egyszerủen összeadnánk az egyes egységek értékeit. Ez az úgynevezett kohéziós hatás, amely bár alapvetően szintén fizikai jelenség, de bizonyos absztrakciókkal élve értelmezhető a társadalom jelenségeire is (Kulcsár 1998). 
A sajátpotenciál problematikája már Stewartnál is felmerült (Stewart 1947), és megoldásának alapja hagyományosan az, hogy közvetett módon, valamilyen 'önmagától vett' távolságot $\left(d_{j j}\right)$ rendelünk a tömeghez $\left(m_{j}\right)$ :

$$
V_{j j}=\frac{m_{j}}{d_{j j}} .
$$

Ez a távolság legszemléletesebben úgy ragadható meg, ha megvizsgáljuk, hogy adott tömeg hogyan és mekkora területen (illetve ebböl továbbszámolt távolságon) oszlik meg. Ilyenkor kézenfekvőnek és egyszerünek tünhet egyenletes tömegeloszlással számolni, azonban tapasztalataink alapján, a társadalmi térben létező tömegekre nézve az egyenletes tömegeloszlás feltételezése általában nem lehet érvényes, gondoljunk például a nagyvároson belüli népességeloszlásra. Ebből indult ki Court is, amikor különböző tömegeloszlási modellek tesztelésével próbálkozott a sajátpotenciál megállapítása céljából (Court 1966). Eredményei megerősítik, hogy valószerủbbnek tủnik valamilyen, az egyenletestől eltérő tömegeloszlást feltételezni, például a népesség esetében, annak területi elhelyezkedését legjobban szemléltető negatív exponenciális eloszlást.

A tơmegeloszlásból adódó távolságérték kiszámítása kiváltható valamilyen egységnyi, az adott társadalmi tömeghez rendelt távolság megadásával. Ennek a keresett egységnyi távolságértéknek a kiszámítása, a sok eltérő vélemény között, tulajdonképpen ugyanazt az elvet kőveti: adott a tömeg (teruletegység) területével megegyező kör, és ennek sugara adja meg a test önmagától vett távolságát. A különbség az egyes eljárások között annyi, hogy a fenti sugárérték hogyan és milyen szempont szerint van súlyozva. A sugár nagyságával megegyező távolságot alkalmaz Nitsch, mely szerinte jól közelíti a területen belüli átlagtávolság értékét (Nitsch 2000). De hasonlóképpen járt el Nemes Nagy is, feltételezve, hogy a tömeg az adott területen a középponttól sugárnyi távolságban oszlik el (Nemes Nagy 1998). Többen javasolják, és talán a legelterjedtebb alkalmazási mód a sugár harmadával számolt sajátpotenciál kalkuláció (Rich 1980; Keeble et al. 1982; Redding-Venables 2001). Ennek magyarázata is a tömegeloszlás valószínüségének meghatározásával van összefüggésben (Frost-Spence 1995). Hasonló következtetésekböl jutott más eredményre például Head és Mayer, akik a sugár kétharmadát tekintik a leginkább elfogadható önmagától vett hozzávetőleges távolságértékként (Head-Mayer 2002).

A sajátpotenciálhoz rendelt távolságként nemcsak az adott egység önmagától vett távolsága használatos, hanem ez a tömeg és szomszédjai átlagos távolságának valahányad részével számolva is megadható. Ily módon végezte a sajátpotenciál kalkulálását Wei, a szomszédoktól való távolság negyedét (Wei 1996), illetve Wolf, ezen távolság felét véve alapul (Wolf 1997). 
Tagai Gergely : A potenciálmodell erényei és korlátai a társadalomkutatásban. Tér és Társadalom 21. évf. 2007/1. 145-158. p.

A sajátpotenciál számítása értelmezhető egyfajta súlyozási problémaként is. Minél kisebb a hozzárendelt távolság értéke, annál nagyobb lesz a sajátpotenciál. Ennek következtében, sok múlik a vizsgálatot végző kutató szándékán is. Ha jobban ki akarjuk emelni a hatóközpontot, mert egyébként a vizsgált társadalmi-gazdasági jelenség jellemzői csorbulnának a potenciálmodellben, a kisebb súly tünik nyilvánvaló választásnak (olyan megoldás is lehetséges, hogy a hatótömeg egy az egyben megegyezik a sajátpotenciállal). Ha viszont a tömeg és távolságértékek alapján valamely hatóközpontok a valóságosnál nagyobb befolyással szerepelnek, nagyobb súllyal és távolsággal, így kisebb sajátpotenciállal lehet csökkenteni a torzulást.

Az alap-potenciálmodell nem csak szükíthető (a sajátpotenciálra), hanem kiterjeszthetỏ a vizsgálati téren kívülre is. Feltételezhetjük, hogy a vizsgált térrészen kívül is vannak olyan központok, amelyek jelentős, hovatovább domináns hatással vannak a térség erỏviszonyaira: például egy ország esetében, nem csak a belső viszonyok alakíthatják, az erőtér szerkezetét, hanem a szomszédos államok értékei is (lásd Trejvis-Kibalcsics 1976). Az úgynevezett külsỏ potenciál ezt a befolyást írja le. Ebben az esetben a számítás formulája úgy módosul, hogy adott tömeg esetében a hatóközpontok helyére a vizsgált téren (belső rendszeren) 'kívüli' egységek kerülnek:

$$
V_{j k}=\sum_{k} \frac{m_{k}}{d_{j k}}
$$

ahol $V_{j k} j$ pont (terület) külső potenciálja, $m_{k}$ pedig egy külső hatóközpont tömege. Egyéb tekintetben az eddig érintett, potenciálszámítással kapcsolatos megfontolások itt is érvényesek.

A külső potenciál bevonásával felállítható egy olyan háromtagú modell, amelyben a sajátpotenciál (1/a. ábra), a (belső) potenciál (1/b. ábra), valamint a külső potenciál (1/c. ábra) együttesen szerepelnek. A teljes potenciál $\left(V_{f t}\right)$ értéke, ami az adott egységre (pont, terület) ható összes befolyást megjeleníti, ezen részek összegéből adódik:

$$
V_{j t}=V_{j j}+V_{j}+V_{j k} \text {. }
$$

Önmagában a sajátpotenciál csupán a hatóközpont saját erejéről tájékoztat minket. A (belsö) potenciál és a sajátpotenciál együttesen a vizsgált térrész belsỏ struktúráját tárja föl, egy teljesen zárt, külső kapcsolatok nélküli térszerkezetet feltételezve. Míg a külsö potenciál bevonásán keresztül, és az elöbbiek együttes alkalmazásával azok az összefüggések kerülnek felszínre, amelyek által a vizsgált térrész jellemzöi egy nagyobb rendszeren belüli helyzete alapján, a belső struktúrákkal együtt értelmezhetök (Nemes Nagy 1998). 


\section{1. ÁBRA}

A sajátpotenciál, a (belsö) potenciál és a külsö potenciál hatásmechanizmusa

(The Scheme of the own, Inner and Outer Potential)

a)

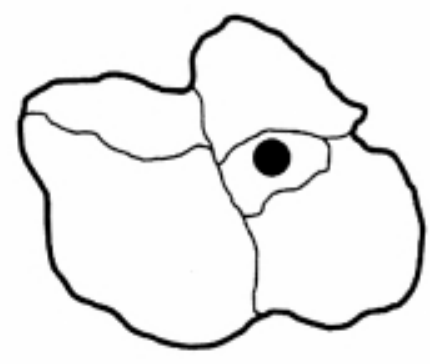

b)

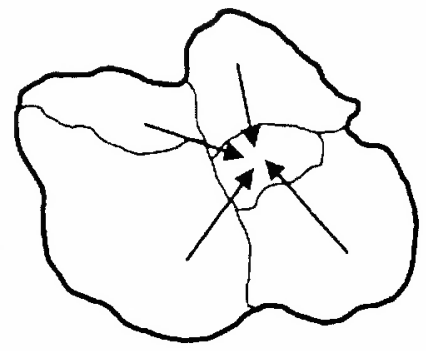

c)

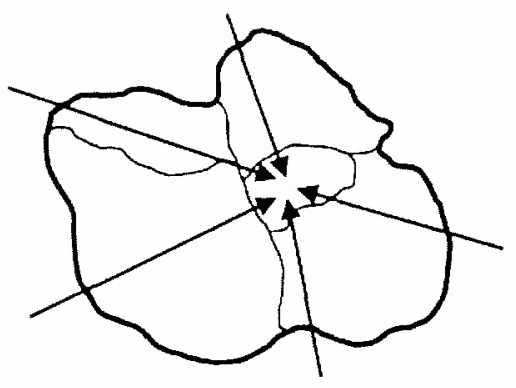

Forrás: Saját szerkesztés.

\section{A potenciál jelentésének értelmezése}

A potenciálmodell használatának néhány elméleti alapkérdésének tisztázása után feltehető a kérdés: mit is jelent valójában a potenciál? Hogyan interpretálható a kiszámolt érték? Mint összetett jelenséget modellezỏ alkalmazás, a potenciál-fogalom sem ragadható meg csak egyféleképpen. Az alkalmazások területén mai is számos különbőző, bár egymással összefüggő értelmezés van jelen. A potenciál-fogalom interpretálását ezért elősegítheti, ha alkalmazásait egy rendszerbe helyezve értelmezzük (2. ábra). (Az ábrán látható nyilak és vonalak a fejlődés irányairól, illetve a különböző alkalmazási lehetőségek összekapcsolódásairól is tájékoztatást nyújtanak.)

A potenciálmodell legelső verziói kísérleti alkalmazásoknak tekinthetők. Ezek kivétel nélkül John Quincy Stewart nevéhez füződnek, aki első ilyen irányú munkáiban olyan példákon keresztül dolgozta ki elméletének alapjait, mint pl. annak vizsgálata, hogy egy adott államból származó egyetemi hallgatók létszáma egy adott egyetemen hogyan viszonyul lakóhelyük és az adott felsőoktatási intézmény távolságához (Stewart 1942). Vagy más példával élve: milyen tényezők határozzák meg egy helyi, de országos ismertségủ hírlap elöfizetőinek vagy egy állami vásár látogatóközönségének 'származási' (területi) megoszlását az Egyesült Államokban (Stewart 1941). Stewart ezen jelenségek vizsgálatával arra a következtetésre jutott, hogy egy 
adott helyről érkező egyetemi hallgatók, vásárlátogatők vagy előfizetések száma egyenesen arányos adott hely (példáiban valamely szövetségi állam) népességével, míg fordítottan arányos az adott hely és a célterület (egyetem, vásár vagy az újságkiadó székhelye) közötti távolsággal. A népesség és a távolság hányadosát Stewart népességi potenciálként azonosította, ami egy társadalmi tömeg adott távolságon belüli hatását hivatott kifejezni (Stewart 1942; Warntz 1964; Nemes Nagy 1998). Ezzel a méröszámmal különféle társadalmi jelenségek térbeli megoszlásának megbecslése vált lehetövé.

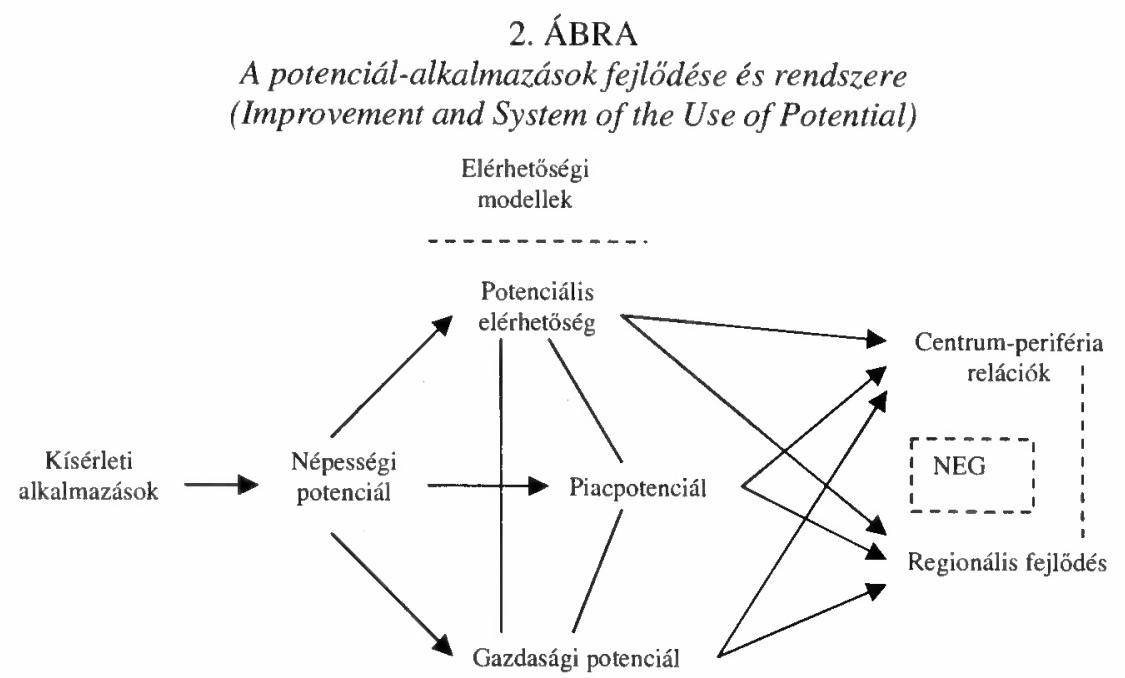

Forrás: Saját szerkesztés.

A későbbi, a népességi potenciált központi fogalomként kezelö munkákban az egyes szerzők általában szintén a társadalmi jelenségek térbeli eloszlásának modellezésére használták (használják ma is) az összefüggést. Az ezekre a vizsgálatokra oly jellemző potenciál-térképek csak később jelentek meg az egyes potenciálértékek kumulálásával (Stewart 1947; 1948), ami azt is jelentette, hogy már nem az egyedi 'erőhatások' voltak a hangsúlyosak, hanem egy komplex rendszerbe foglalva (valamely térség egészét lefedve) egy adott társadalmi jelenség összetett térbeli megoszlási viszonyai váltak megismerhetővé.

A kiindulási potenciál-koncepció a felhasználások bövülésével folyamatosan átalakult, és ennek nyomán váltak szét - igaz nem túl éles határok mentén - a különféle alkalmazási lehetöségek is. A népességi potenciál hatás jellege valamelyest háttérbe szorult - éppen azáltal, hogy a későbbi vizsgálatokban nem az egyes potenciálokat, hanem ezek összegzett értékeit vették figyelembe -, és értelmezhetövé vált úgy is, mint egy hely közelségét mérő jelzőszám (Stewart 1948; Warntz 1955; Stewart-Warntz 1958). Egy hely közelsége vagy ellenkezöleg, elszigeteltsége adott rendszer (például egy ország) népessége számára, annak elérhetőségét jelenti. Mivel a jobban elérhető helyeken nagyobb a valószínüsége a társadalmi kölcsönhatások bekövetkezésének, 
ezért az elérhetőséget kezdetben úgy értelmezték, mint az emberek közötti interakciók lehetőségének vagy a társadalmi intenzitásnak mérőszámát (Pooler 1987), visszakanyarodva ezzel a potenciál hatóerỏ jellegéhez. Némi módosulással ez a jelentéstartalom épült be a szélesebb körben értelmezett elérhetőségi fogalomkör potenciális elérhetöség kifejezésébe. Az elérhetőség kérdésének ebből a szempontból való közelítése azért érdemelhet kiemelt figyelmet, mert nem csak a távolság fizikai jellemzői alapján van meghatározva, hanem a társadalom egységei, egyedei felöl is.

A népességi potenciálnak még szintén Stewart és Warntz bábáskodása mellett kialakult egy, az elöbbiekkel rokon változata, amely újabb alkalmazási lehetőségek kialakulásához és a potenciál-koncepció további finomodásához, tágulásához vezetett. Az alapmodellhez képest annyi módosulás következett be, hogy tömegként nem a népességszám, hanem az egy fỏre jutó jövedelem népességgel súlyozott változata - azaz tulajdonképpen a jövedelemtömeg - szerepelt (Warntz 1956, 1959; Stewart-Warntz 1958). Látható, hogy ennek meggondolásnak abból a szempontból van jelentősége, hogy kiemelje a népesség, mint 'jövedelemtermelő népesség' szerepét, mint ami például az elérhetőségi viszonyokban hangsúlyozottan fontos tényező. Ha az elérhetőséget nem mint valamilyen általános társadalmi kérdést kezeljük, hanem gazdasági megfontolások alapján azt tartjuk szem előtt, hogy gazdasági szempontból minek az elérhetösége fontos, akkor a jövedelemtermelö népesség, mint piac jut szerephez. A piacok elérhetősége avagy a piacpotenciál alapvetően befolyásolja a piaci tényezőket: a kereslet-kínálat viszonyát vagy éppen az árakat (Harris 1954; Warntz 1956).

Ha némileg elvonatkoztatunk a potenciál mint elérhetőségi tényező jelentésétöl, akkor a jövedelmi potenciál - vagy ahogy Warntz nevezte, 'bruttó gazdaságinépességi potenciál' (Warntz 1956) - a gazdaság területi képéröl szolgáltathat kiegészítő információkat. Így, gazdasági potenciálként értelmezve a jövedelmi potenciált, a gazdasági élet két alapvetô oldalának mechanizmusai is magyarázhatóvá válnak: például lakossági jövedelmekkel számolva a fogyasztási oldal, a piac jelenségei, míg a nemzeti jövedelem alapján figyelembe vett gazdasági potenciál vizsgálata esetén a termelési oldal egyes jelenségei tárhatók fel inkább.

Ahogy az eddigiekből is kitünik, a potenciális elérhetőség, a piacpotenciál, valamint a gazdasági potenciál koncepciói számos ponton találkoznak egymással, $\mathrm{s}$ közös érintkezési felületük kiterjedtsége miatt a továbblépés irányai is hasonlók. Az elỏbbiek során felvázolt potenciál-alkalmazások bizonyos elemei érintik a gazdasági élet egyes, gyakorlati szempontú közelítést igénylő problémáit, mint például a telepítés, a telephelyek kérdéskörét. Az elérhetöség szerepe, a piacok nagysága és helyzete a gazdasági fejlettség állapota (így együtt: a relatív helyzet) olyan tényezők, amelyek meghatározók a telepítési szempontokra nézve, így a potenciálmodell alkalmazása az ilyen irányú vizsgálatokban szintén relevánsnak tünik.

A potenciálmodell változatai - azáltal, hogy kihangsúlyozzák a fekvés, a relatív helyzet szerepét - egy újfajta szemlélettel járultak hozzá a regionális fejlődésfejlettség értelmezéséhez. Ez a gondolat olyan közgazdasági irányzatokkal is kapcsolatba hozható, mint például a Paul Krugman neve által fémjelzett Új Gazdaság- 
Tagai Gergely : A potenciálmodell erényei és korlátai a társadalomkutatásban.

Tér és Társadalom 21. évf. 2007/1. 145-158. p.

földrajz elmélete (New Economic Geography, NEG - Krugman 1991), amely a regionális fejlődés és fejlettség különbségeinek magyarázatában a fekvés bevonása által jut el egyik központi fogalmához, a centrum-periféria relációhoz, mint a tér szerkezetét formáló tényezö kiemeléséhez (Niebuhr 2004; Fingleton 2005).

Ezek alapján, hogy a potenciál egy tömeg adott távolságon belüli hatásának kifejezése, a társadalmi intenzitás mérőszáma, elérhetöségi mutató, fejlettséget magyarázó tényezö, vagy valamilyen tömegeloszlási viszonyszám-e? Nehéz ezt pontosan meghatározni, mivel hasonló tartalmak keverednek a különféle értelmezésekben, akár még egy konkrét modellen, alkalmazáson belül is. Viszont a sokszor csak árnyalatnyi jelentésbeli különbségek legfeljebb a rendszerezö szándékot nehezítik, mintsem egymással állnának ellentmondásban; együttes jelenlétük hozzásegít a vizsgálandó jelenség, mint egész megértéséhez, több oldalról közelítve hozzá.

\section{Összegzés}

A potenciálmodell fizikai analógiája, habár mint törvény nem állja meg a helyét a társadalmi térben, mégis hasznos ismereteket hordoz. A tömegek és távolságok tapasztalati úton is igazolható összefüggései által feltárhatók a társadalmi jelenségek térbeliségének sokszor rejtve maradó jellemzöi. A modellépítés átfogó ismerete, a különbözö potenciálváltozatok alkalmazása segít áthidalni a tér és az abban létező entitásokkal kapcsolatos vizsgálati problémákat (például a térfolytonosság, a sajátpotenciál kérdései). Csak ezek tisztázása után valósulhat meg a potenciál-fogalom értelmezése és a modell értékelése.

Mindemellett a modell megítélése nem egyértelmủ. Az elméleti igazolás, a modell felépítésének és interpretálásának nehézségei olyan problémáként vetődhetnek fel, amelyek sok esetben korlátozhatják használhatóságát. Viszont azzal, hogy a fekvés vagy relatív helyzet megjelenítésével a potenciálmodell a térbeli jelenségeket nem önállóan értékeli - hanem egy rendszer részeként, melynek elemei hatással vannak egymásra -, a térkapcsolatok elemzésében így is kiemelkedỏ szerephez jut.

\section{Irodalom}

Bene L.-Tekse K. (1966) Vizsgálatok a népesség területi eloszlásának alakulásáról Magyarországon 1900-1960. - KSH Népességtudományi Kutatócsoport Közleményei. 9. Budapest.

Carey, H.C. (1859) Principles of Social Science. Lippincott, Philadelphia.

Court, A. (1966) Population Distribution and Self-Potentials. Mimeographed paper, Departement of Geography, San Fernando Valley State College.

Dusek T. (2003) A gravitációs modell és a gravitációs törvény összehasonlítása. - Tér és Társadalom. 1. $41-58.0$.

Fingleton, B. (2005) Testing the 'New Economic Geography': A Comparative Analysis Based on EU Regional Data. Kiel Summer Workshop on Trade and Location.

Frost, M.E.-Spence, N.A. (1995) The Rediscovery of Accessibility and Economic Potential: The Critical Issue of Self-potential. - Environment and Planning A. 27. 1833-1848. o.

Harris, C.D. (1954) The Market as a Factor in the Localization of Industry in the United States. - Annals of the Association of American Geographers. 44. 315-348. o.

Head, K.-Mayer, T. (2002) Illusory Border Effects: Distance Mismeasurement Inflates Estimates of Home Bias inTrade. Manuscript. 
Tagai Gergely : A potenciálmodell erényei és korlátai a társadalomkutatásban.

Tér és Társadalom 21. évf. 2007/1. 145-158. p.

Keeble, D.-Owens, P.L.-Thompson, C. (1982) Regional Accessibility and Economic Potential in the European Community. - Regional Studies. 16. 419-432. o.

Krugman, P. (1991) Increasing Returns and Economic Geography. - Journal of Political Economy. 99. 483-499. 0.

Kulcsár G. (1998) A gravitációs és potenciálmodell társadalomföldrajzi alkalmazásai. Kézirat, ELTE TTK Regionális Földrajzi Tanszék.

Nemes Nagy J. (1998) A földrajzi helyzet szerepe a regionális tagoltságban. - Fazekas K. (szerk.) Munkaeröpiac és Regionalitás. MTA KK KI, Budapest. 147-165. o.

Niebuhr, A. (2004) Market access and regional disparities. - New economic geography in Europe. HWWA Discussion Papers.

Nitsch, W. (2000) National Border and International Trade: Evidence from the European Union. Canadian Journal of Economics. 22. 1091-1105. o.

Pooler, J. (1987) Measuring Geographical Accessibility: A Review of Current Approaches and Problems in the Use of Population Potentials. - Geoforum. 18. 269-289. o.

Ravenstein, E.G. (1889) The Laws of Migration. - Journal of the Royal Statistical Society. 52. 241-305. o.

Redding, S.J.-Venables, A.J. (2001) Economic Geography and International Inequality. Manuscript, London School of Economics.

Rich, D. (1980) Potential Models in Human Geography. - Concepts and Techniques in Modern Geography. 26. Geo Abstracts, Norwich.

Schäffle, G. F. (1878) Bau und Leben des sozialen Körpers. Tübingen.

Sheppard, E.S. (1979) Geographic Potentials. - Annals of the Association of American Geographers. 69. 438-447. 0.

Stewart, J.Q. (1941) An Inverse Distance Variation for Certain Social Influences. - Science. 93. 89-90. o.

Stewart, J.Q. (1942) A Measure of the Infulence of a Population at a Distance. - Sociometry. 5. 63-71. o.

Stewart, J.Q. (1947) Empirical Mathematical Rules Concerning the Distributions and Equilibrum of Population. - Geographical Review. 37. 461-485. o.

Stewart, J.Q. (1948) Demographic Gravitation: Evidence and Application. - Sociometry. 11. 31-58. o.

Stewart, J.Q.-Warntz, W. (1958) Macrogeography and Social Science. - Geographical Review. 48. 167-184. o.

Stouffer, S.A. (1940) Intervening Opportunities: A Theory Relating Mobility and Distance. - American Sociological Review. 5. 845-867. o.

Tobler, W. (1970) A Computer Movie Simulating Urban Growth in the Detroit Region. - Economic Geography. 2. 234-240. o.

Trejvis, A.I.-Kibalcsics, M.O. (1976) Kísérlet a potenciál-módszer alkalmazására a Szovjetunió regionális iparföldrajzi helyzetének térképészeti elemzésében, a szomszédos országok figyelembevételével. Nemes Nagy J. (szerk.) Regionális gazdaságfóldrajzi olvasókỏnyv II. Tankönyvkiadó, Budapest.

Warntz, W. (1955) A Methodological Consideration of Some Geogrephic Aspects of the 1955 Newfoundland Conederation with Canada, 1949. - The Canadian Geographer. 6. 39-49. o.

Warntz, W. (1956) Measuring Spatial Association with Special Confederation of the Case of Market Orientation of Production. - Journal of the American Statistical Association. 51. 597-604. o.

Warntz, W. (1959) Geography at Mid-Twentieth Century. - World Politics. 11. 442-454. o.

Warntz, W. (1964) A New Map of the Surface of Population Potentials for the Unites States, 1960. Geographical Review. 54. 170-184. o.

Wei, S-J. (1996) Intra-National Versus International Trade: How Stubborn are Nations in Global Integration? - National Bureau of Economic Research Working Paper. 5531. o.

Wolf, H.C. (1997) Patterns of Intra- and Inter-State Trade. - National Bureau of Economic Research Working Paper. 5939. o.

Young, E.C. (1924) The Movement of Farm Population. Cornell Agricultural Experiment Station. Bulletin. 426. 0 .

\section{Jegyzet}

${ }^{1}$ A tanulmány a 2006. november 18-án, az ELTE-n tartott Regionális Modellek c. tudományos konferencián elhangzott előadásra épül. 


\section{VIRTUES AND LIMITS OF POTENTIAL MODEL}

\section{GERGELY TAGAI}

The paper investigates the basic issues of the application of potential model. Within the framework of that, the author makes an attempt to review some of the essential problems of the model's functional principles and theoretical verification, as well some distinctiveness of its structure and special variations. The comprehensive knowledge of the model building helps to recognise the investigational problems between the space and the entities existing in it. The virtues and limits of the model don't appear through a direct opposition, but they are shown in an indirect way, according to the purpose of the author, by the exploration and valuation of the model's typical issues of use. By emphasizing the relationship between masses and distances, which can be confirm empirically, the potential model helps to discover those characteristics of the social structures, which are often hidden. The complex system of field of applications alludes to the variegation of the model and the potential concept, besides, reveals its position and role in the spatial analysis especially in the investigation of spatial interactions. 